\title{
Lithological subdivision and petrology of the Great Himalayan Vaikrita Group in Kumaun, India
}

\author{
K S VALDIYA and O P GOEL \\ Department of Geology, Kumaun University, Nainital 263002 , India
}

MS received 10 December 1982

\begin{abstract}
The Vaikrita Group made up of coarse mica-garnet-kyanite and sillimanite-bearing psammitic metamorphics constituting the bulk of the Great Himalaya in Kumaun is divisible into four formations, namely the Joshimath comprising streaky, banded psammitic gneisses and schists, the Pandukeshwar consisting predominantly of quartzite with intercalations of schists, the Pindari made up of gneisses and schists with lenses of calc-silicate rocks and overwhelmingly injected by Tertiary pegmatites and granites (Badrinath Granite) leading to development of migmatites, and the Budhi Schist comprising biotite-rich calc-schists. The Vaikrita has been thrust along the Main Central Thrust over the Lesser Himalayan Munsiari Formation made up of highly mylonitized low-to meso-grade metamorphics, augen gneisses and phyllonites.

Petrological studies demonstrate contrasting nature of metamorphism experienced by the Vaikrita and the Munsiari rocks. Sillimanite-kyanite-garnet-biotite-muscovite ( $\pm \mathrm{K}$-feldspar and \pm plagioclase). - quartz metapelites and interhanded calc-schists and calc-gneisses with mineral assemblages of calcite-hornblende-grossular garnet, labradorite ( $A n_{50}-A_{n_{65}}$ ), ( $\pm \mathrm{K}$ feldspar)-quartz ( \pm biotite), and hornblende-diopside \pm labradorite \pm quartz. suggest medium to high grade of metamorphism or indicate upper amphibolite facies experienced by the rocks of the Vaikrita Group. The assnciated migmatites, granite-gneisses and granites of the Pindari Formation were formed laige,y as a result of anatexis of metapelites and metapsammites. While, the sericite-chlorite-quartz and muscovite-chlorite-chloritoid-garnetquartz, assemblages in metapelites and epidote-actinolite-oligoclase $\left(A n_{20}\right)$-quartz and epidote-hornblende-andesine $\left(A_{29}\right) \pm$ quartz in the metabasites suggest a low-grade metamorphism (greenschist facies) for the Munsiari Formation, locally attaining the lower limit of medium-grade (epidote-amphibolite) facies.

The inferred $\mathbf{P}$-T conditions obtained from textural relations of various mineral phases and the stability relationship of different coexisting phases in equilibrium, suggest that the temperature ranged between $600^{\circ}$ and $650^{\circ} \mathrm{C}$ and pressure was over $5 \mathrm{~kb}$ for the Vaikrita rocks. The mineral assemblages of the Munsiari Formation indicate comparatively lower P-T conditions, where the temperature reached approximately $450^{\circ} \mathrm{C}$ and pressure was near $4 \mathrm{~kb}$.

The rocks of the two groups were later subjected to intense shearing. cataclasis and attendant retrograde metamorphism within the zone of the Main Central (= Vaikrita) Thrust.
\end{abstract}

Keywords. Vaikrita: Munsiari formations; Tertiary; mylonitized; lithology: petrology; Great Himalaya.

\section{Introduction}

The bulk of the snowy mountain range in the central belt of the Himalaya, represented by pre-eminent peaks of Nandadevi $(7817 \mathrm{~m})$, Trishul $(7120 \mathrm{~m})$, Dunagiri $(7066 \mathrm{~m})$ and Panch Chuli $(6904 \mathrm{~m})$, is constituted of Precambrian metamorphic rocks of upper amphibolite facies and extensively intruded in the northern part by late-to posttectonic Tertiary granite. This Great Himalayan lithological assemblage was desig- 
nated as the Vaikrita by Greisbach $(1891,1893)$ and Valdiya $(1973,1979,1981)$ and as the "Central Crystalline Zone" by Heim and Gansser (1939). The thrust-bound homoclinal slab of huge dimension ( 6000 to $12,000 \mathrm{~m}$ thick) has been interpreted variously as the root of the crystalline nappe covering the sedimentary formations of the Lesser Himalaya (Auden 1937; Heim and Gansser 1939; Berthelsen 1951; Hagen 1958; Valdiya 1962) and as the remobilized Precambrian geanticlinal basement ridge that has been spectacularly uplifted (Pande and Saxena 1968; Saxena 1971; Mehdi et al 1972). According to Powell and Conaghan (1973), the Himalayan "Central Gneiss" represents regenerated older rocks within the Indian continental crust.

The easterly extension of the Vaikrita is named differently in different parts of Nepal such as "Tibetan Slab" (Dalle du Tibet) by Lombard (1958) and Bordet (1961). 'Annapurna Gneissic Complex' by Bodenhausen et al (1964), Himalayan Gneiss Zone by Hashimoto et al (1973), K humbu Nappe by Hagen (1958) and Barun Group by Jaros and Kalvoda (1976). Further east, it is known as Darjeeling Gneiss in Sikkim Himalaya, as Thimpu Formation (Nautiyal et al 1964) or Chasilakha-Takhtsang Gneiss (Gansser 1964) in Bhutan, and as Sela Group (Das et al 1975) in Kameng District of Arunachal Himalaya. To the northwest, the extension of the Vaikrita has been observed east of Karcham in the Satluj valley. The Zanskar Range of northeastern Kashmir probably represents the northwestern continuation of the Vaikrita. The Padar in Kishtwar (Jangpangi et al 1978) and Giambal in southeastern Ladakh (Srikantia and Bhargava 1978) are probably correlatable with the Vaikrita.

The present work embodies the petrological studies of the Vaikrita Group and the Munsiari ( = Jutogh) Formation of the 'Central Crystalline Zone' of Heim and Gansser (1939) in the central sector of the Himalayan arc (figure 1). The lithological mapping and tectonic studies have been carried out by the first author (KSV) and the petrological studies by the second (OPG). An endeavour has been made through the present study to bring out the distinction in the petrological characters of two group of rocks, the Vaikrita and the Munsiari.

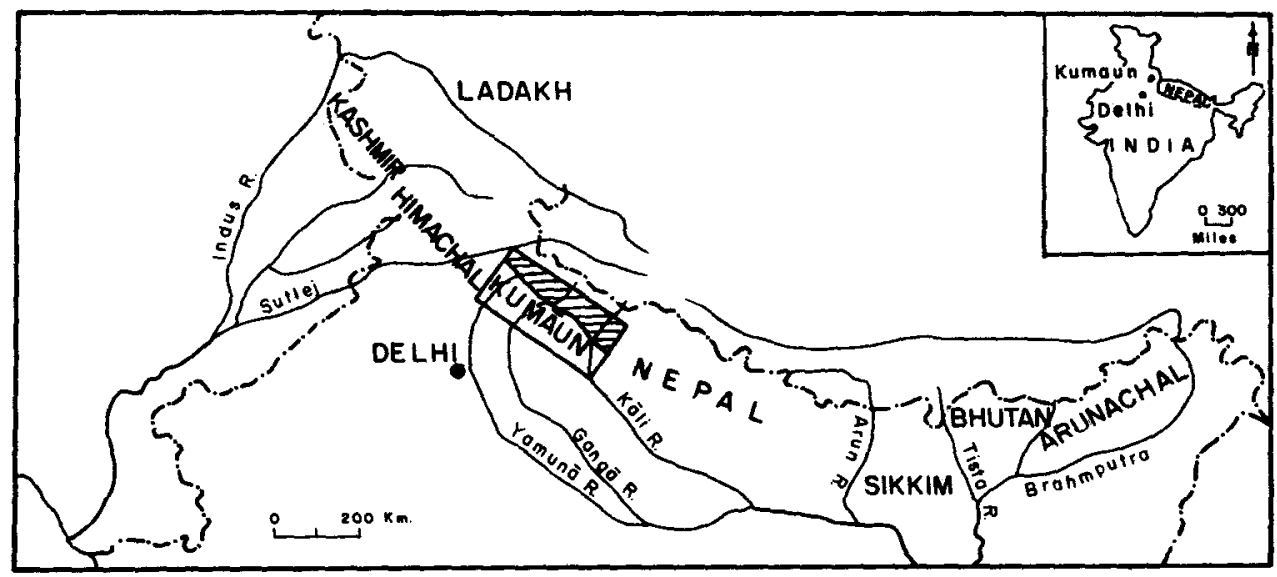

Figure 1. Location of the area of study in the Kumaun Himalaya - the central sector of the Himalayan arc. 
Gansser (in Heim and Gansser 1939), describing in some detail the petrologicmineralogic characters of the Great Himalayan rocks of Kumaun, attempted a petrological zonation of the sequence in the Kali valley in the eastern border. Dave and Rawat (1968), Kumar et al (1970) have also given a general account of these rocks. In recent years Powar (1972), Misra and Bhattacharya (1977) and Gupta (1978) have dealt with the petrogenesis of the rocks discernible in the Kali, Pindar and Alaknanda valleys, respectively. Detailed petrochemical studies of the Tibetan Slab in the Annapurna-Dhaulagiri massif have been carried out by Le Fort (in Bordet 1971; Bordet et al 1972; Pecher 1977).

\section{Tectonic Setting}

As already alluded to, the Great Himalaya is a huge homoclinal tectonic slab (figure 2) delimited by intracrustal thrusts (Valdiya 1979, 1980). The moderately dipping Main Central (= Vaikrita) Thrust separates the higher-grade Vaikrita rocks above from the low-grade metamorphics of the Lesser Himalayan Munsiari Formation. The Munsiari itself has been thrust over the sedimentaries and represents the root of the crystalline nappes that cover a large part of the Lesser Himalaya (Valdiya 1977, 1979). The Munsiari extends westwards to join up with the Jutogh Formation of Himachal Pradesh. The Vaikrita Thrust which Valdiya $(1979,1980)$ recognizes as the real Main Central Thrust, is a zone of extreme shearing, cataclastic deformation and metamorphic retrogression. The width of the thrust zone varies from a few metres to about a kilometre. The general strikes in the different formations of the Vaikrita Group are: WNW-ESE with gentle dip of $25^{\circ}$ towards NNE of the Joshimath Fm., variable with $35^{\circ}$ towards $\mathrm{N}$ or NNE in the Pandukeshwar and in E-W to WNW-ESE with dip varying from $35^{\circ}$ to $40^{\circ}$ towards $N$ to NNE in the Pindari Fm. (Tara Chandra, Personal Communication).

In the north the steeply inclined Malari Fault/ Thrust sharply cuts off the Vaikrita rocks from the sedimentaries of the Tethyan domain that stretches over the IndoTibetan borderland. In a cross-section (figure 3), the Malari appears to be a reverse fault that has truncated both the Vaikrita and Tethyan rock formations, attenuating and beheading the former and cutting the base of the latter. The emplacement of granite and attendant migmatization has taken place generally in the upper (northern) part, obliterating the structural relationship between the various units. All workers excepting Valdiya $(1977,1979,1980)$ include the Munsiari Formation within the gamut of the "Central Crystalline Zone". The Munsiari metasediments indicate greenschist facies of metamorphism, and their gneissic components (mainly augen gneisses) exhibit pronounced cataclastic deformation and attendant retrograde transformations. Moreover, the style and orientation of the first-generation folds (isoclinalreclined with axes trending $\mathrm{NE}-\mathrm{SW}$ and having $25^{\circ}$ plunge in the Munsiari rocks) are very different from those of the Vaikrita (also isoclinal to reclined having variable trend from E-W to ENE-WSW with 20 to $25^{\circ}$ plunge towards E or ENE and superimposed with second-generation tight overfolds or isoclines trending NW-SE to NNW-SSE and plunging NW (Tara Chandra, Personal Communication). It is, therefore, difficult to subscribe to the contention of Hashimoto et al (1973) in case of Nepal sector, that the augen gneisses are derived from the Himalayan (Vaikrita) gneisses and metasomatically modified by the granitic material introduced along the shear zone. Nor the plea of Thakur (1977) seems plausible that the metamorphic grade decreases both upward and downward from the sillimanite-migmatite zone. 


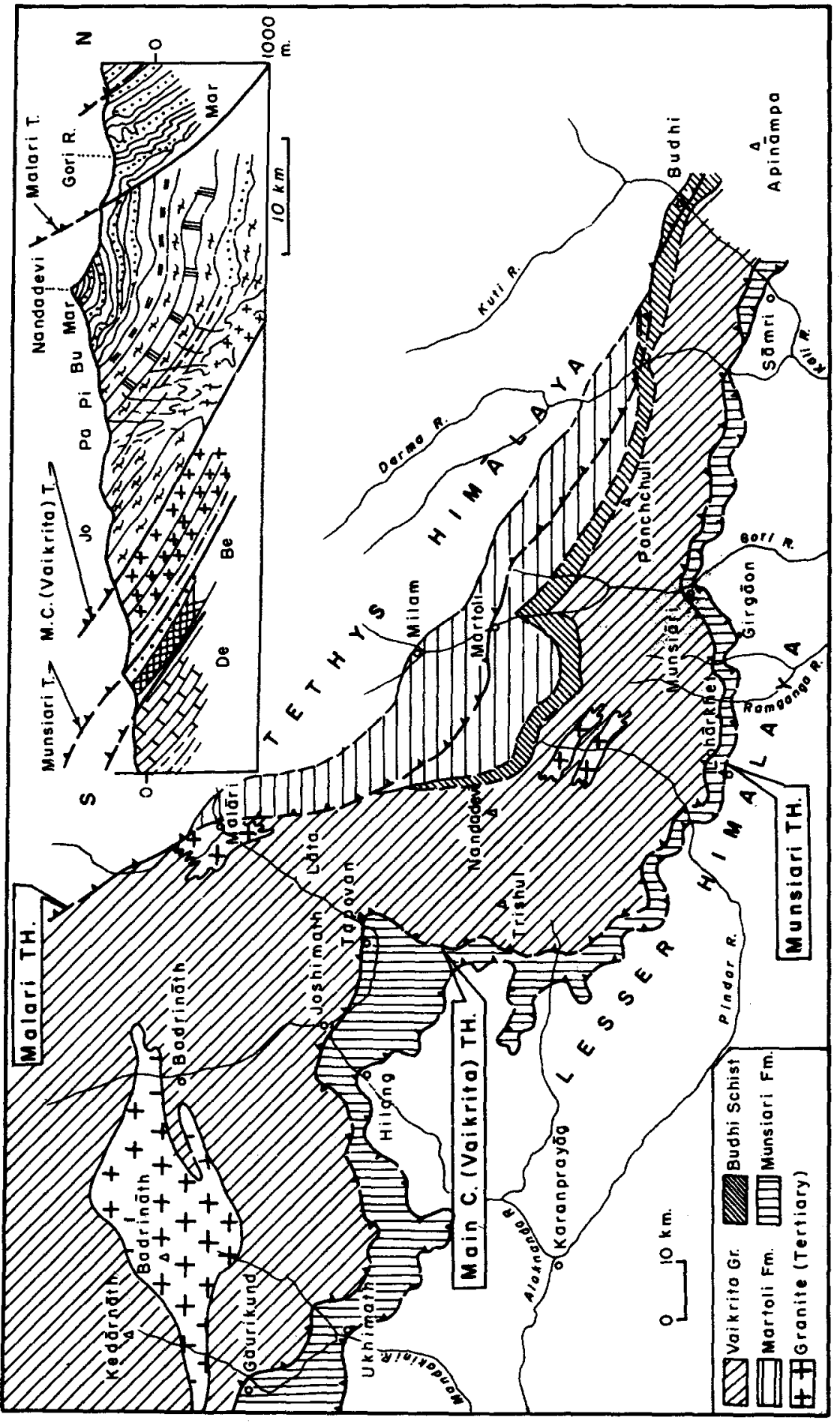

옹

号

远

总.

$\cong 0$

皮 11

뜰 울

空

蛋

Е

总

造

हृ

范

这空焉

की

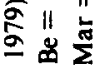

究这

흔

氜㖞

ฐญ

है क

을.

密方

空位

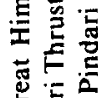

焉

洁

䒿焉

른

过

\&U

ri

논

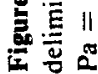




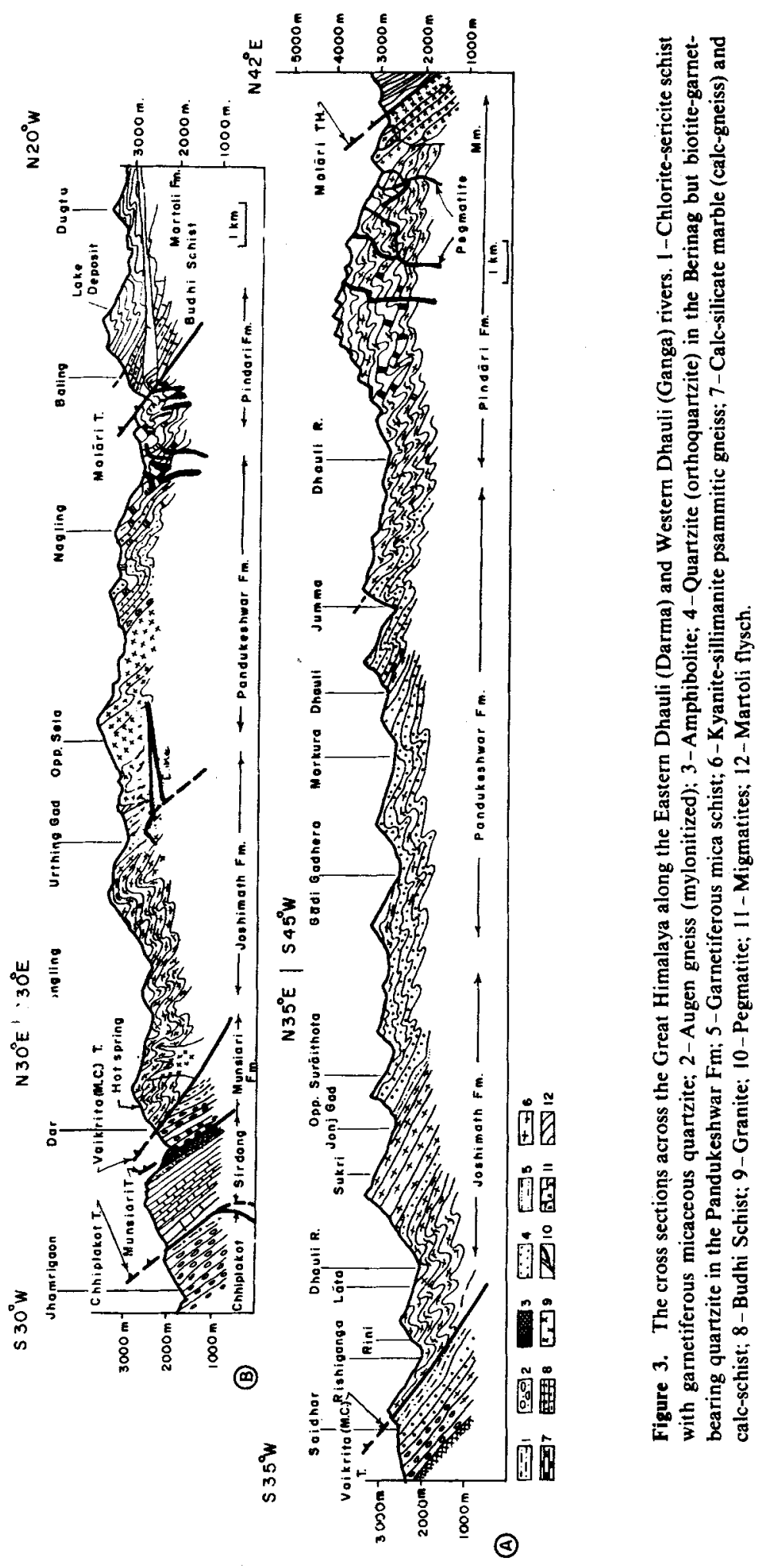




\section{Lithological Subdivision}

The earliest attempt to give an account of petrological subdivision within the Vaikrita succession discernible in the Kali valley was made by Gansser (in Heim and Gansser 1939). Designating the Vaikrita as the "Central Crystalline Zone" Gansser identified eight zones (a to $h$ ), the first of which is a part of the Munsiari Formation and the last one being the basal member of the Garbyang Formation of the Tethyan facies. A four-fold classification of the "Tibetan Slab" in the Annapurna Range has been proposed by Le Fort (in Bordet 1971; Bordet et al 1972), but the sequence and content of the four units are somewhat different from those of Gansser. The present lithological subdivision (table 1) based on the traverses taken by Valdiya in the valleys of Kali, Darma (Eastern Dhauli), Gori, Pindar, Western Dhauli, Alaknanda, Mandakini, Bhagirathi and Tons, is an elaboration of the scheme outlined by Valdiya (1973).

Table 1. Lithological subdivision of the "Central Crystalline Zone" in Kumaun.

Tectonic
Unit

Tethyan Martoli Formation of greywacke-slate alternation or Garbyang Formation of Facies argillocalcareous sediments.

\section{Malari Thrust/Fault}

(4) Budhi Schist: Biotite porphyroblastic calc-schist interbedded with micaceous schist. and phyllites toward the top. Locally, carbonaceous, pyritic, or staurolite-bearing. (= Gansser's zone $\mathrm{g}$ )

(3) Pindari Formation: Predominantly banded lime-silicate gneiss and marble interbedded with subordinate biotite-psammitic gneisses and schists with or without kyanite and sillimanite.

Extensively penetrated by network of dykes and veins of aplite, pegmatite and granite. Pervasive penetration and invasion of granite plutons (e.g. $18 \mathrm{~m} . \mathrm{y}$. old Badrinath) has brought about wide-spread migmatization and development of porphyroblastic augen

Vaikrita gneisses, characterized by sillimanite and garnet.

Group (= Zones e and $f$ of Gansser)

(2) Pandukeshwar Formation: Biotite- and/or muscovite-rich quartzite intercalated with kyanite-garnet-bearing mica schists and psammitic gneiss. Locally, lenses and subordinate layers of calc-silicate gneisses and garnet-bearing amphibolite. Where garnet has developed in abundance, the quartzite resembles leptynitic granulite. (= Gansser's zone d)

(1) Joshimath Formation: Streaky and banded - and kyanite-rich biotite-psammitic gneiss. Interbedded with garnet-kyanite-biotite schists and at the base, with phyllonites. Very subordinate and local lenses of calc-silicate gneiss. (= Zone $\mathrm{c}$ of Gansser)

\section{Main Central (Vaikrita) Thrust}

Munsiari Profoundly mylonitized gneisses of granodioritic. granitic and aplitic composition, grading Formation locally into augen mylonite. Interbedded with chlorite-sericite schist, graphitic schist and crystalline blue-grey limestone. (= Zones a and b of Gansser) 


\section{Petrography of the Vaikrita and Munsiari Metamorphics}

The crystalline rocks of the Vaikrita Group in the valleys of Dhauli, Pindar and Darma show progressive metamorphism, reflected in the gradual coarsening of grain-size, decrease in the amount of muscovite and increase in quartzo-feldspathic material which resulted in a gradual change from schists through migmatites to granite-gneisses and granites. The rocks are medium to coarse-grained. having schistose to gneissose textures. In the Pindari, the rocks show well-developed foliations and in the Budhi Schist compositional banding is very characteristic such as noticed near Malari.

The different stable assemblages as observed in various formations are given below:-

\subsection{Munsiari Formation}

A-Pelitic and psammitic compositions:

Quartz-sericite-chlorite

Quartz-muscovite-chlorite-biotite-garnet \pm chloritoid-plagioclase \pm epidote-tourmaline.

Quartz-plagioclase-biotite \pm garnet \pm muscovite.

Quart7-K-feldspar-muscovite \pm biotite.

B -- Basic composition:

Epidote-actinolite-plagioclase $\left(A n_{7}-A n_{15}\right)$-quartz.

\subsection{Joshimath Formation}

A - Pelitic composition:

Quartz-muscovite-biotite-garnet-kyanite \pm plagioclase.

Quartz-muscovite-biotite-kyanite \pm fibrolite (-plagioclase).

B - Quartzofeldspathic composition:

Quartz-K feldspar-plagioclase-biotite \pm muscovite.

\subsection{Pandukeshwar Formation}

A- Pelitic composition:

Quartz-biotite-kyanite-sillimanite-plagioclase \pm K-feldspar.

Quartz-biotite-sillimanite-muscovite-K-feldspar \pm garnet.

B - Quartzofeldspathic composition:

Quartz-plagioclase-microcline-biotite \pm garnet ( - sillimanite)

\subsection{Pindari Formation}

A- Pelitic composition:

Quartz-biotite-garnet-staurolite-plagioclase.

Quartz \pm muscovite-sillimanite-plagioclase ( \pm K-feldspar). 
B - Quartzofeldspathic composition:

Quartz-muscovite-biotite \pm garnet-plagioclase (myrmekite)-K-feldspar.

Quartz-biotite (-sillimanite)-plagioclase-K-feldspar-garnet (myrmekite).

\subsection{Pindari and Pandukeshwar Formations:}

C-Calcareous composition:

Epidote-calcite-sphene-quartz-biotite ( \pm muscovite).

Zoisite-actinolite-calcite-sphene(-quartz) grossularite \pm amphibole.

Zoisite-actinolite-calcite-sphene(-quartz).

Talc-tremolite/actinolite (-quartz).

Calcite-hornblende-plagioclase $\left(A n_{50-60}\right)$-quartz-microcline ( \pm biotite).

Hornblende-diopside \pm calcite-scapolite $\mp$ quartz \pm labradorite.

\subsection{Budhi Schist}

Chlorite-garnet-muscovite-biotite \pm staurolite-K-feldspar-plagioclase-quartz.

The mineral assemblages recognized from Joshimath through Pandukeshwar, Pindari to Budhi Schist in the Vaikrita Group indicate progressive upward decline in the grade of metamorphism. In the Pindari Formation, the migmatites and gneisses show such varied features as veinlets. arterites and stromatic bands and even porphyroblastic to augen structures (figures $4 a, b$ ) which are often associated with tourmaline-rich muscovite-granite. The mineral assemblages of the rocks of the Munsiari, on the other hand, clearly indicate greenschist facies assemblage and indicate extensive retrogression of the feld spathic gneisses.

In the following pages the authors describe the salient features of the different mineral constituents of the rocks of the Vaikrita Group and the Munsiari Formation with special reference to the stability of the phase associations in the rocks. This is specially desired in view of the possible processes that might have occurred as a consequence of post-tectonic intrusions of granitic rocks, as stated earlier.

In contrast to the Munsiari rocks, the Pandukeshwar and the Pindari Formations show granoblastic mosaic of quartz grains. The triple-point junctions at approximately $120^{\circ}$ angle with one another (figure 5a) indicate low-energy boundaries and thermodynamic equilibrium in the rocks (Kretz 1966; Vernon 1968). However, near the thrust plane (MCT) the Vaikrita Group of rocks (e.g. Joshimath Fm.) shows quartz in aggregation of minute crystals and occurs as elongated grains with undulose extinction (figure $5 b$ ).

Muscovite is a ubiquitous mineral in all the assemblages and is also found in migmatites, quartzofeldspathic gneisses and granites. The amount decreases in the higher grade metapelites in which kyanite and/or fibrolitic sillimanite and sillimanite - $K$-feldspar are the dominating phases in the rocks of the Pandukeshwar and Pindari, suggesting a reaction:

$$
\text { Muscovite }+ \text { quartz }=\mathrm{K} \text {-feldspar }+\mathrm{Al}_{2} \mathrm{SiO}_{5}+\mathrm{H}_{2} \mathrm{O}
$$

which demarcates the upper limit of amphibolite facies (Chatterjee and Johannes 1974). In the Munsiari muscovite is pleochroic in shades of green to pale green and is probably phengitic. 

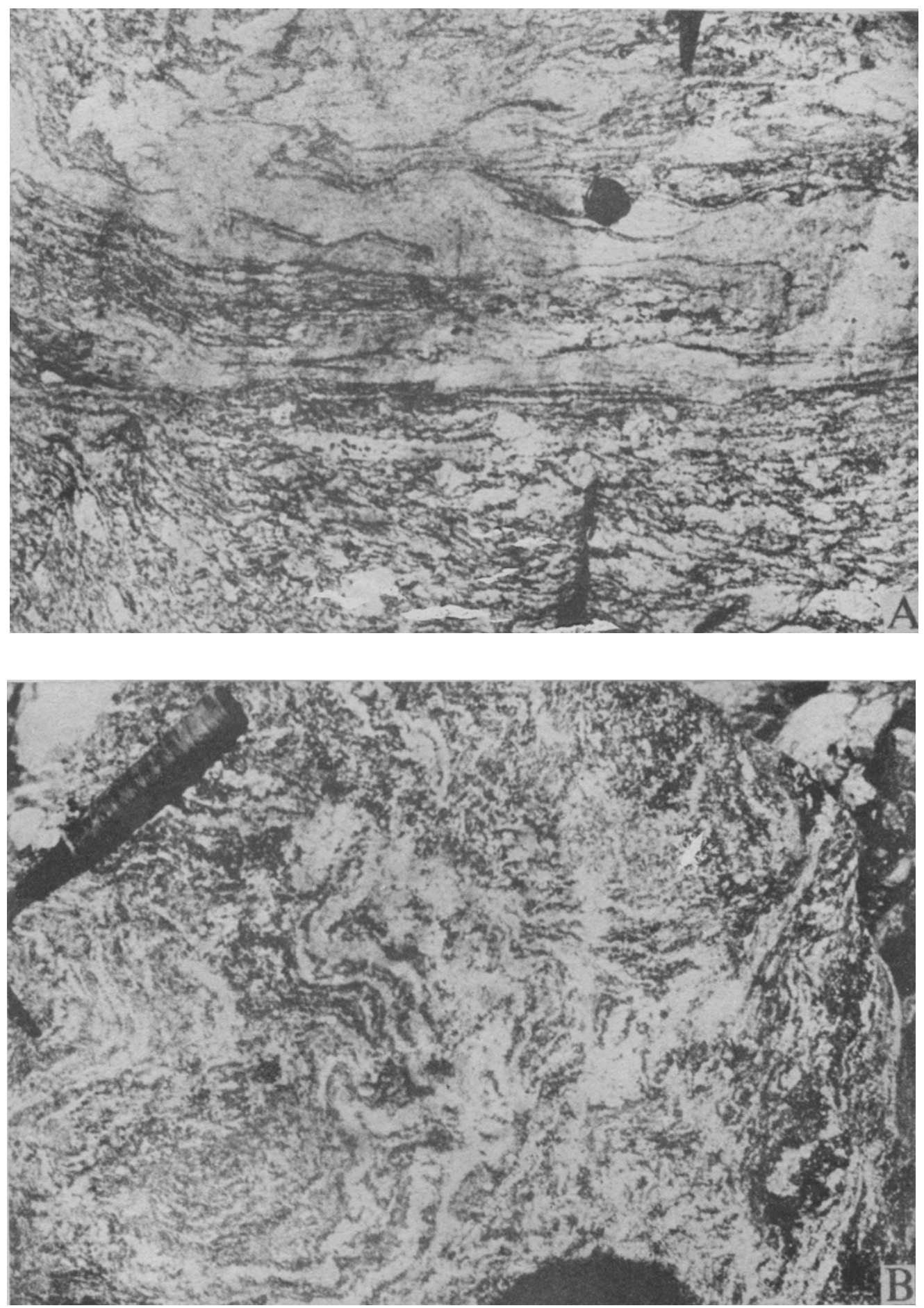

Figure 4. (a) Migmatite (phlebitic to arterite), Pindari Fm., Near Bogdiar, Gori valley. (b) Malari Mignatite, Pindari Fm. Locality: Bhapkund, W. Dhauli valley. 

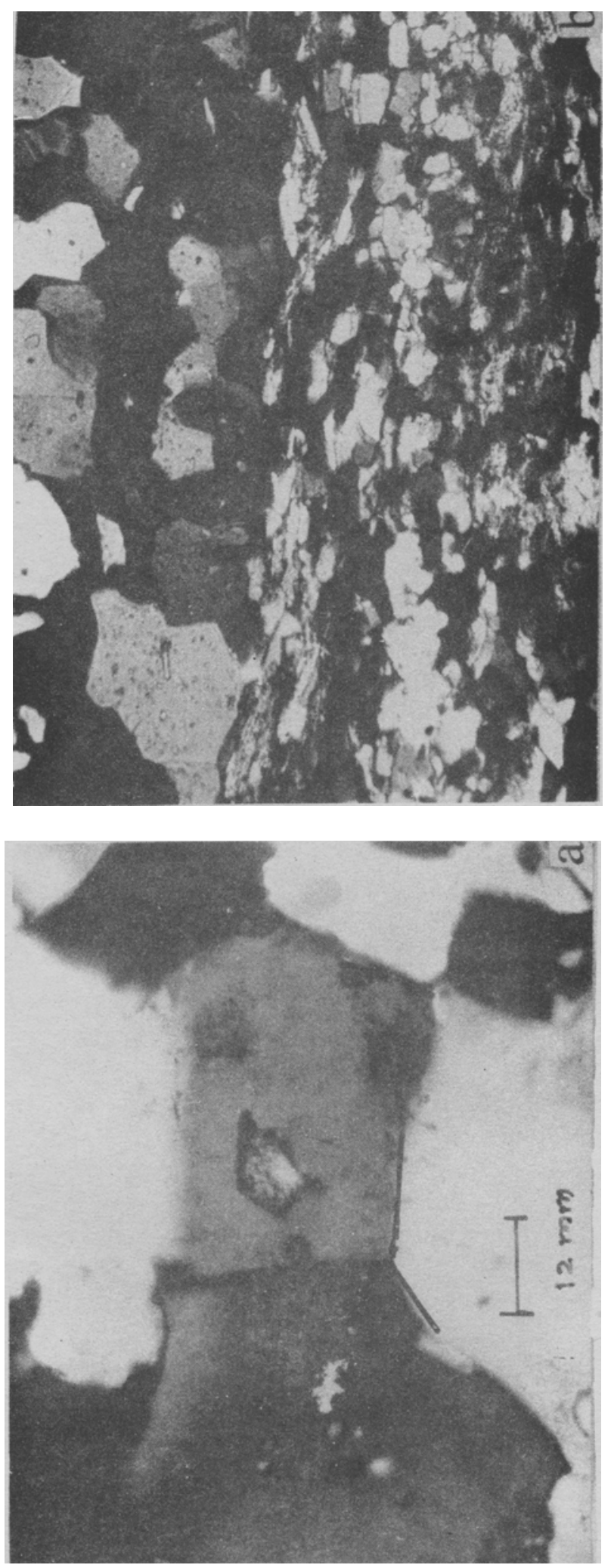

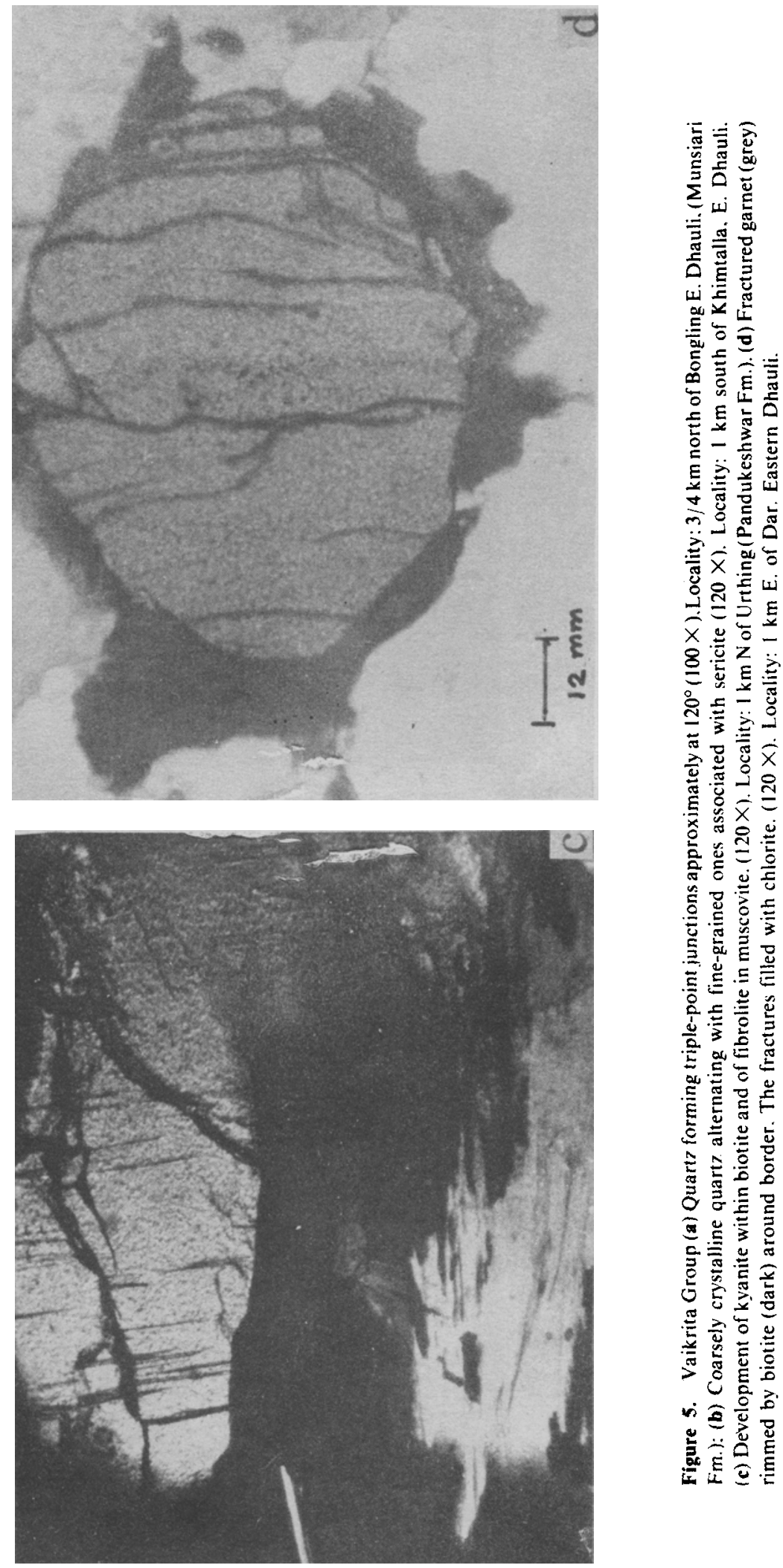

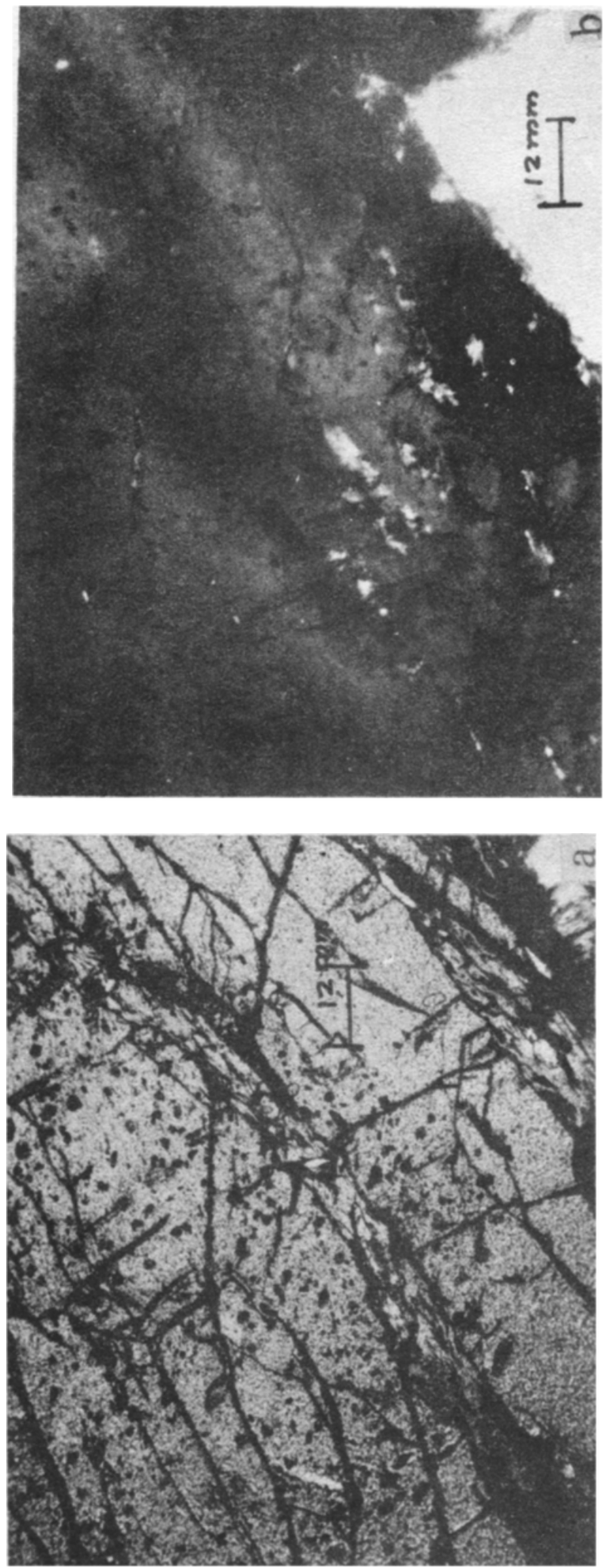


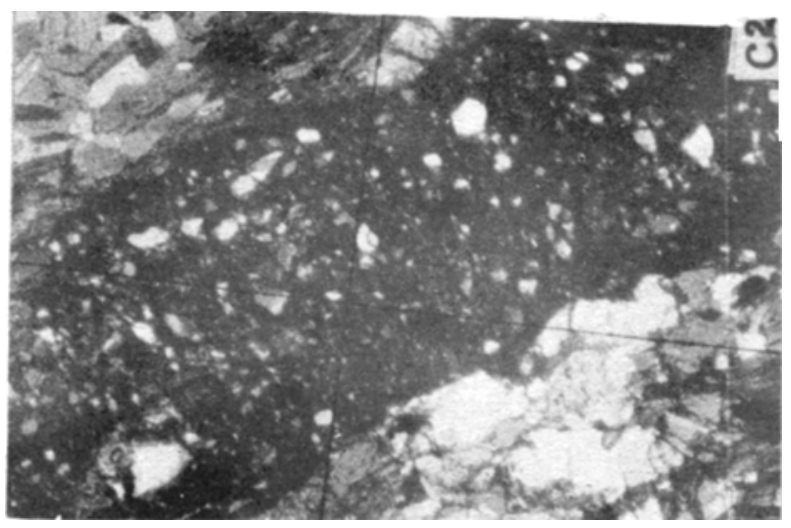

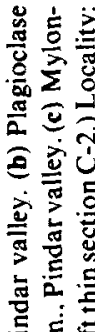

证导

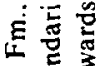

흘

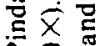

용

$\dot{\bar{x}}=$

ิㅡㄹ

$=$

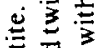

昰

政

드

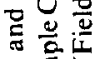

을

동

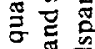

둔

点

要

至

$=\frac{9}{\square}$

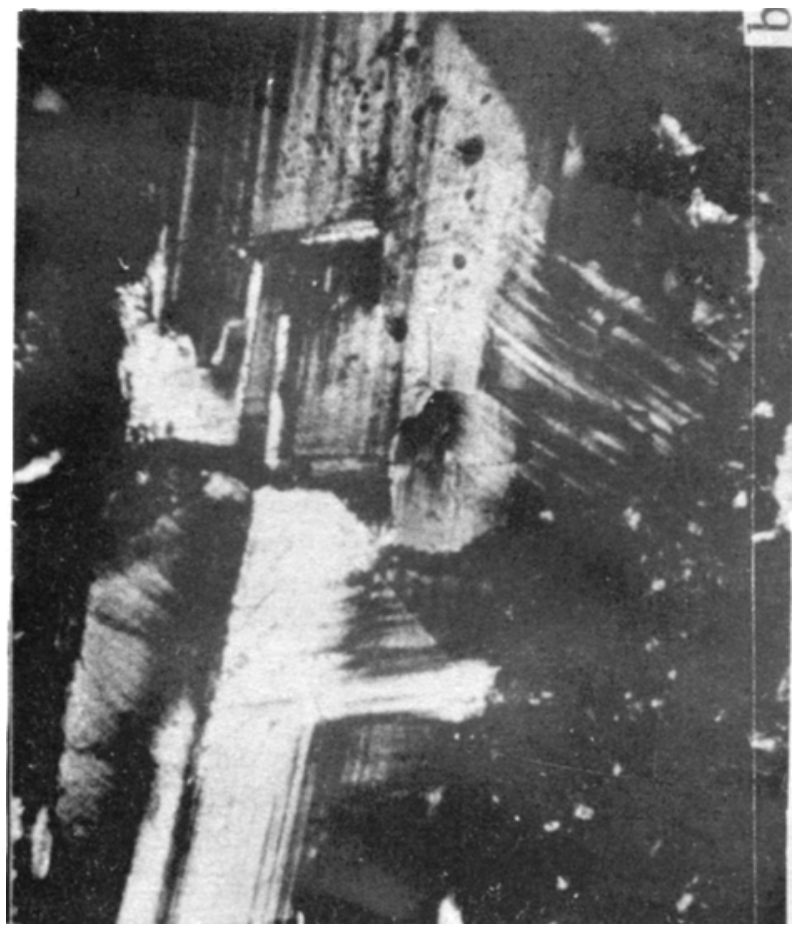

远

至丞

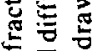

뭏

诃

氮密

일

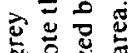

4 든

䘮

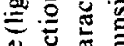

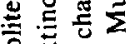

올 $\frac{w}{4}$

密

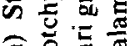

응 둥

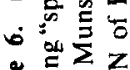

总总总㤩 
In a progressive phase of metamorphism the development of kyanite and fibrolitesillimanite seems to have taken place along the grain boundaries of muscovite flakes. (e.g. in rock sample No. D-50).

Primary chlorite is absent in rocks of the Vaikrita. In the Munsiari rocks, however, it occurs as thin, pleochroic greenish flakes in equilibrium with garnet and chloritoid.

Chloritoid occurs sparsely in the Munsiari rocks, as porphyroblasts showing pleochroism in the shades of bluish-green to pale-green and is characterized by prolific inclusions of magnetite and occasionally quartz. The rare occurrence of chloritoid in metapelites is not only suggestive of large $\mathrm{Fe}: \mathrm{Mg}$ ratio, relatively high $\mathrm{Al}$ content and low amount of alkalies of the bulk composition, but its association with chlorite and muscovite is a strong indicator of low-grade metamorphism of green-schist facies.

Biotite exhibits a considerable variation in grain-size, shape and colour from one litho-unit to another. The porphyroblastic biotite of the Pindari metapelites contains inclusions of zircon, ilmenite and quartz. It is intimately associated with kyanite (figure $5 c)$ and in some cases with fibrolitic sillimanite as seen in a Joshimath rock $3 / 4 \mathrm{~km}$ north of Bagling. Such an association indicates its formation by the following reaction:

$$
\text { Staurolite }+ \text { muscovite }+ \text { quartz }=\text { biotite }+ \text { kyanite or sillimanite }+ \text { garnet. }
$$$$
\text { (Hoschek 1969) }
$$

Garnet occurs as small crystals in the Munsiari rocks and as large well-developed porphyroblasts, the diameter of which ranges from a few $\mathrm{mm}$ up to $20 \mathrm{~mm}$, in the Vaikrita, particularly in the Pandukeshwar and the Pindari formations. Along the MCT zone in the Munsiari and basal part the Joshimath rocks, the garnet grains show evidence of strong deformation and attendant diaphthoresis as borne out by chlorite, biotite and epidote formed extensively around the grains and along the fractures (figure 5d).

Kyanite is a common mineral in the rocks of the Vaikrita Group, but strikingly absent in the Munsiari rocks. In view of the coexistence of kyanite in equilibrium with biotite, garnet, muscovite and quartz and the absence of staurolite in these rocks, but its (staurolite) presence in the overlying Budhi Schist, the formation of kyanite is attributed to the reaction mentioned above in connection with biotite (e.g. see Sharma and Narayan 1975).

Sillimanite is less common than kyanite and occurs generally as a fibrolitic felted mass. Granular form is also observed in the Pindari metapelites. The textural relations between biotite, muscovite and quartz suggest its formation by the breakdown of muscovite, that is muscovite + quartz $=$ sillimanite $+\mathrm{K}$-feldspar $+\mathrm{H}_{2} \mathrm{O}$ (Chatterjee and Johannes 1974). The heat given out by post-tectonic Badrinath Granite seems partly responsible for this reaction as borne out by the widespread presence of sillimanite in the Pindari Fm. conspicuously intruded by granite and pegmatite.

The Vaikrita Group locally shows (e.g. sample No. D-57 of the Pandukeshwar Fm.) coexistence of kyanite and sillimanite, suggesting that either the P-T conditions were very close to the kyanite-sillimanite univariant curve or that the dehydration reaction (see e.g. No. 3, figure 7) was subsequently placed to higher temperature, whereby sillimanite was produced and kyanite continued to exist metastably.

Staurolite is of rare occurrence, and only in the Pindari rocks of the Vaikrita. It is completely absent in the Munsiari. The idioblastic and pleochroic porphyroblasts in the Pindari rocks (figure 6a) contain few inclusions of quartz and magnetite. In view of 
its occurrence in the kyanite-bearing assemblage, it can be related to the reaction equation (2), which seems to have reversed because of decreasing load pressure or that staurolite got stabilized because of its higher zinc content (Guidotti 1970).

Hornblende is present in calc-schists and calc-gneisses of the Pindari Fm. and in the epidote-amphibolites of the Munsiari Fm. In the latter it occurs as prisms exhibiting pleochroism in shades of pale-green to bluish-green and showing small extinction angle $\left(C \wedge Z=15 \pm 2^{\circ}\right)$ and is actinolitic. In contrast, the hornblende of the Pindari Fm. occurs as porphyroblasts showing yellowish-green to greenish-brown colour. Such a colour has been taken to indicate a higher grade of metamorphism and higher Ti content (Gable and Smith 1975; Miyashiro 1973). It is also characterized by large extinction angle $\left(\mathrm{C} \wedge \mathrm{Z}=28^{\circ} \pm 2^{\circ}\right)$ and schiller inclusions of magnetite.

Diopside occurs sporadically in association with hornblende, biotite, plagioclase. scapolite and quartz in the assemblages of the calca reous rocks of the Pinda ri Fm. It is xenoblastic to idioblastic, optically positive. feebly pleochroic in shades of pale bottle-green to green colour, has large extinction angle $\left(C \wedge Z=44^{\circ} \pm 2^{\circ}\right)$ and thus appears to be hedenbergitic.

Epidote occurs in equilibrium and is compatible with calcite, dolomite and quartz. This suggests that the upper limit of reaction - epidote + quartz $=$ grossularite + magnetite, has not surpassed the temperature of equilibrium investigated by Liou (1973).

Scapolite is observed to occur in association and in equilibrium with diopside (hedenbergitic), hornblende, plagioclase, $\mathbf{K}$-feldspar and quartz from the Pindari rocks (e.g. D-49).

Plagioclase is quite common in the Vaikrita rocks, particularly in quartzofeldspathic gneisses and migmatites. It occurs as porphyroblasts, characterized by numerous inclusions of quartz and sillimanite. The composition of plagioclase varies from albite and oligoclase-andesine $\left(\mathrm{An}_{22}-\mathrm{An}_{27}\right)$ in the Munsiari rocks; to andesine $\left(A n_{35}\right)$ in the Joshimath and the Pandukeshwar psammopelites and to labradorite $\left(A n_{55}-A n_{65}\right)$ in the Pindari calc-gneisses. Thus it is apparent that the composition of plagioclase depends mainly on the bulk-rock chemistry. A characteristic feature of the Pindari plagioclases is their 'splotchy extinction' (figure 6b), a feature generally shown by high-temperature feldspars (Mackenzie $1^{\text {ne }}$ "and by amphibolitic plagioclases (Cannon 1966). The plagioclases form perthitic intergrowth (mainly patch-, vein- and string-perthite) with the alkali-feldspars in the Pandukeshwar and the Pindari rocks. The patch-perthite suggests prevalence of high temperature (Agrawal et al 1972).

Potash-feldspar is generally absent in the assemblages of the Joshimath, though occurs sporadically in the Pandukeshwar and is quite common in the migmatites and calc-gneisses of the Pindari and Budhi Schist. In the gneisses of the Munsiari, microcline occurs as elongated and stretched lenticular augen porphyroblasts. Whereas in the migmatites and granite-gneisses within the Pindari Fm., it shows variation in microclinic twinning pattern. In the higher-grade rocks the feldspar becomes subperthitic to microperthitic, approaching the character of orthoclase characterized by small to moderate optic axial angle $\left(2 \mathrm{~V}_{\alpha}=50-60^{\circ}\right)$.

\section{Retrograde Metamorphism}

The high-grade minerals have suffered marked retrogressive changes, the degree of diaphthoresis being more severe in the proximity of the Main Central Thrust, as evident in the augen gneisses of the Munsiari. In the thrust zone, marked extensive 
sericitization of feldspars and muscovite, chloritization of biotite and garnet, epidotization of garnet and hornblende, and obliteration of the earlier fabric are discernible. The cataclastic fabric of the Munsiari rocks such as streaky (flaser) banding exhibited by augen gneisses (figure $6 \mathrm{c}$ ), flattening of quartz and feldspar-porphyroblasts and the formation of chlorite, biotite and epidote in the fractures of garnet (figure 5d), bear indisputable testimony to dislocation metamorphism.

The alteration of diopside, hornblende and of garnet to epidote (+ clinozoisite) in the calc-gneisses, the pinnitization of biotite, the extensive sericitization of alkali feldspars and deformation of twin-lamellae of plagioclase of the Pindari gneisses indicate retrogressive changes either along so far unrecognized intraformational thrust planes in the higher level of the Vaikrita succession or perhaps are induced by hydrothermal solutions derived from post-tectonic granites. The recrystallization in these sheared rocks probably outlasted the deformation. It can, therefore, be concluded that the progressive regional metamorphism was followed by intense shearing and attendant cataclasis, and retrogression of the augen gneisses to mylonites and phyllonitization of schists when the Joshimath gneisses rode over the Munsiari rocks along the Main Central Thrust.

\section{P-T Conditions}

The presence of kyanite and almandine garnet in the pelitic composition of the Vaikrita Group rocks suggest that minimum pressure was of the order of $4.5 \mathrm{~kb}$, when the triple-point positions of Al-silicate polymorphs (Holdaway 1971; Richardson et al 1969 ) and the experimental results of Hirschberg and Winkler (1968) are taken into consideration. The upper pressure limit cannot, however, be lowered because no phase such as cordierite could have formed in these rocks due to compositional constraints. As will be shown later, the rocks have higher $\mathrm{Fe} / \mathrm{Mg}$ ratio which prohibited the development of cordierite in them. The temperature limits seem to be fixed in view of the experimental results on the mineral equilibria pertinent to the rocks of the area.

The widespread zone of muscovite-sillimanite with $\mathrm{K}$-feldspar in the Vaikrita Group rocks further suggests that temperatures were close to the muscovite + quartz $=$ sillimanite $+\mathrm{K}$-feldspar reaction, for which equilibrium data have been provided by various workers, for example Althaus et al (1970) and Chatterjee and Johannes (1974). The occurrence of migmatitic rocks and the widespread development of quartz-K-feldspar-plagioclase in the psammitic gneisses suggest that the temperature had been above the minimum melting of granite (Tuttle and Bowen 1958). From this it is concluded that the temperatures were in the range $600-670^{\circ} \mathrm{C}$ at regional pressures of $5.7 \mathrm{~kb}$ (when stratigraphic thickness is taken into consideration). A similar temperature value is also obtained when the development of diopside (Winkler 1976) and scapolite (Goldsmith and Newton 1977) is taken into consideration.

The equilibrium paragenesis, diopside-tremolite-calcite-quartz, observed in calcareous rocks lies within a narrow temperature range for considerable variation in $\mathrm{XCO}_{2}$ and possibly indicates a temperature between $540^{\circ} \mathrm{C}$ and $655^{\circ} \mathrm{C}$ and pressure 1 and $5 \mathrm{~kb}$. Further, the occurrence of scapolite with hornblende, biotite, garnet, $\mathrm{K}$-feldspar (perthite) and quartz probably indicates that the conditions of metamorphism locally reached upper amphibolite or lower granulite facies. The presence of biotite and hornblende indicates high $\mathrm{PH}_{2} \mathrm{O}$ and correspondingly low $\mathrm{PCO}_{2}$, which is quite likely as the emplacement of granitic melt was synchronous with regional metamorphism ( $c f$ Powar 1972). 


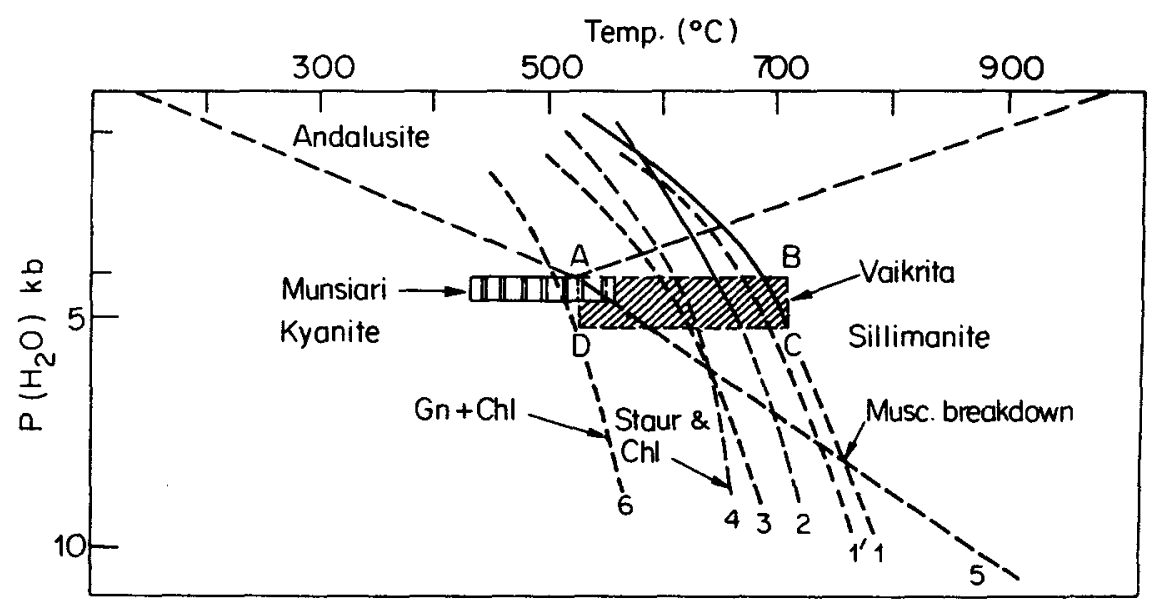

Figure 7. Approximate P-T conditions for metamorphic regimes of the Vaikrita Group (ABCD field with slanting lines) and the Munsiari Fm. (vertical lines). Curves in figure refer to: (1) Breakdown of muscovite in the presence of Quartz, (Evans 1965). (1) Reaction of Mus $+\mathrm{Ab}=\mathrm{Sill}+\mathrm{Ksp}$ (Evans and Guidotti 1966); (2) Breakdown of staurolite (Hoschek 1969); (3) Breakdown of paragonite in the presence of Quartz, based upon natural assemblages given in Guidotti (1974); (4) Reaction of St $+\mathrm{Chl}=\mathrm{Sill}+$ Bio, Equation 3 of Guidotti (1975): (5) Al-Silicates, (Newton 1969); (6) Reaction of $\mathrm{Gn}+\mathrm{Chl}=\mathrm{Sill}+$ Bio (Guidotti 1974).

At these temperatures the Badrinath Granite pluton could not produce any thermal aureole, for the temperature between the regionally metamorphosed rocks and the post-tectonic intrusions did not differ significantly. However, when the rocks were quenched and unloaded, the thrusting phenomenon including cataclasis occurred whereby earlier progressive minerals were changed into lower-grade association, as in the Joshimath (basal Vaikrita). The Munsiari Formation has characteristically a green-schist facies assemblage and the gneissic or granitic basement of this formation was subjected to a more intense deformation as a consequence of thrusting. The metamorphism of the Munsiari Fm is typically in the temperature range of $450-500^{\circ} \mathrm{C}$, in view of the presence of chloritoid and its association in equilibrium with garnet-chlorite-muscovite (Thompson 1976) (see figure 7). However, no feldspathization is discernible in these rocks since the Badrinath Granite intruded only at high levels whereby the Pandukeshwar and Pindari formations were injected profusely by the quartzo-feldspathic material and even locally resulted in partial melting.

\section{Chemical Petrology}

The rocks representing different mineral assemblages from the Vaikrita Group (13 samples) and the Munsiari Formation ( 9 samples) were spectrochemically analysed for their major elements by the methods suggested by Shapiro and Brannock (1962) with slight modification for the kyanite- and sillimanite-bearing rocks. The chemical analyses of the rocks with characteristic mineral assemblage and their oxidation ratios are shown in tables 2 and 3. The analyses are plotted in the ACF and AKF diagrams (figures 8 and 9) along with the average analyses of pelites (Shaw 1956), Pierre Shale, Littleton Shale and carbonate-free shales (all from Orville 1969), and greywackes (Pettijohn $1963,1969)$ with the field of greywackes after Winkler (1967, figure 10) for comparison. 


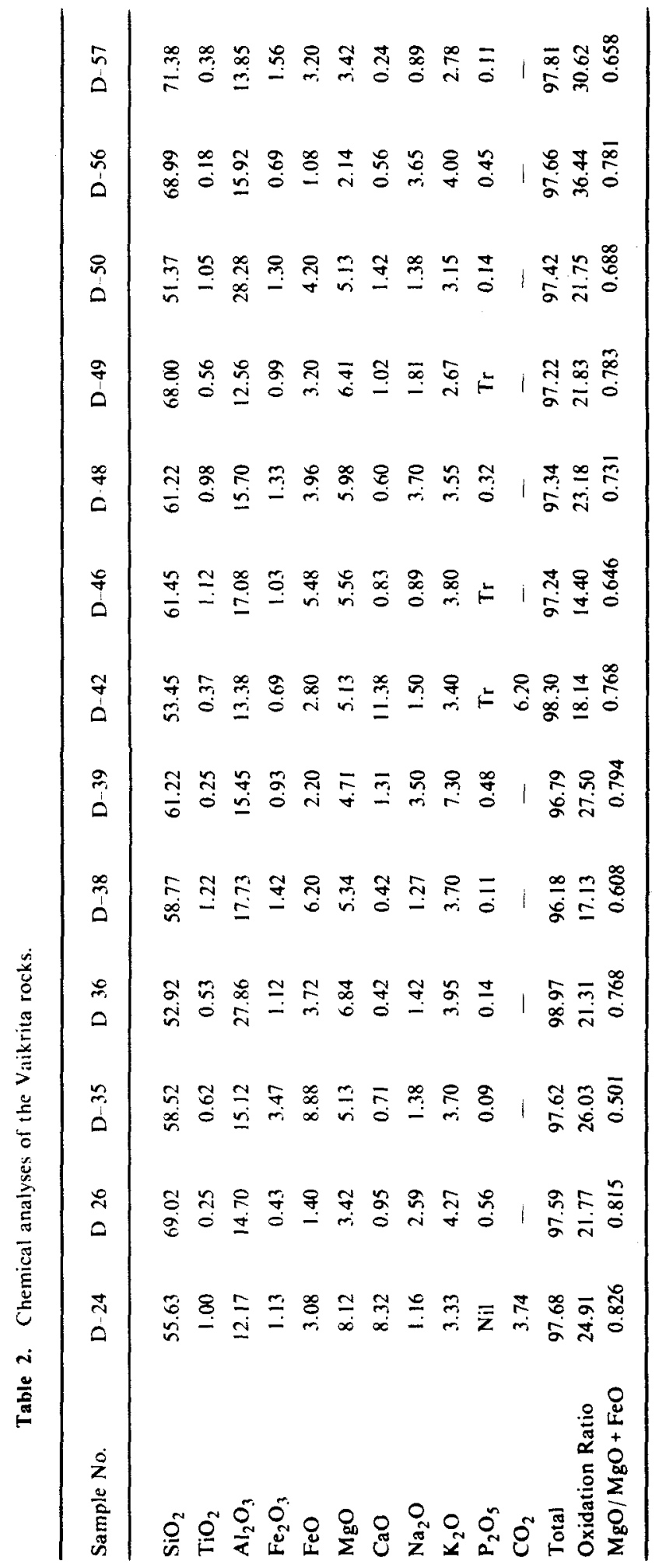




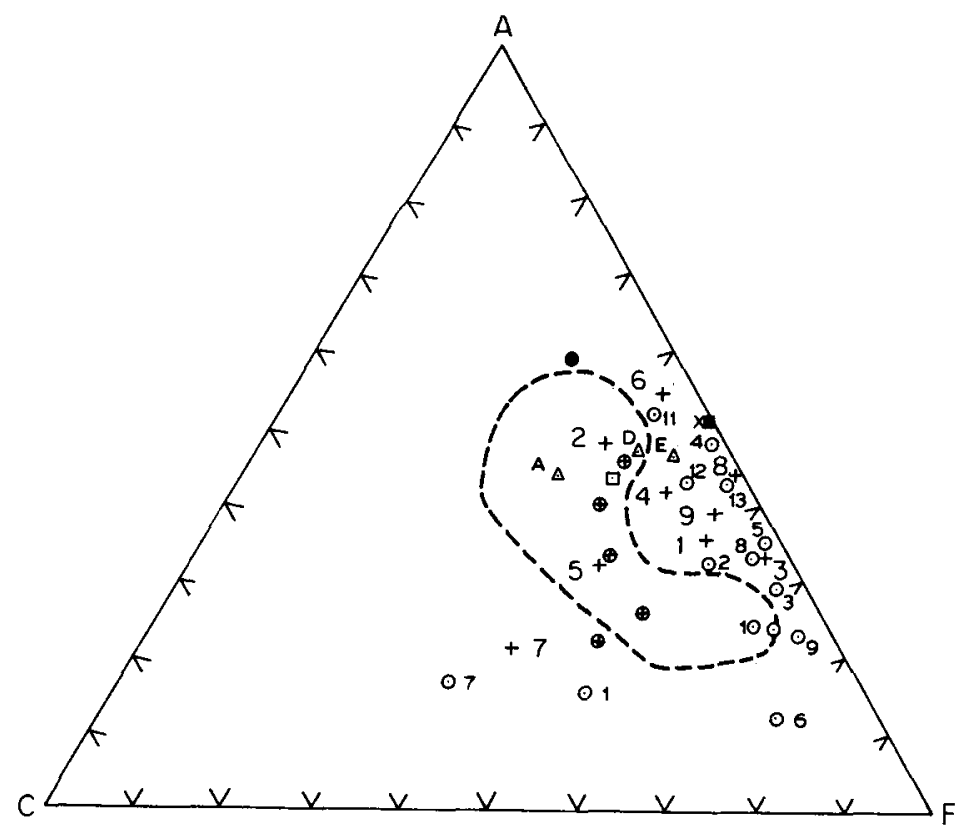

Figure 8. ACF diagram for rocks of the Vaikrita Group. (1-13) and the Munsiari Fm. + 1-9 compared with the average pelite, (Shaw, 1956) (曰), average Pierre Shale $(\bullet)$, carbonatefree shale $(\boldsymbol{D})$ and averages of shale $\Delta$ (A Clark). Slate ( $\Delta$ D Eckel), Precambrian Slates $\Delta$ (Manz) and averages of greywackes ( $\Theta$ ), after Pettijohn. (1963, 1969), Average Littleton Shale $(X)$. Field of greywackes after Winkler (1967, figure 10).

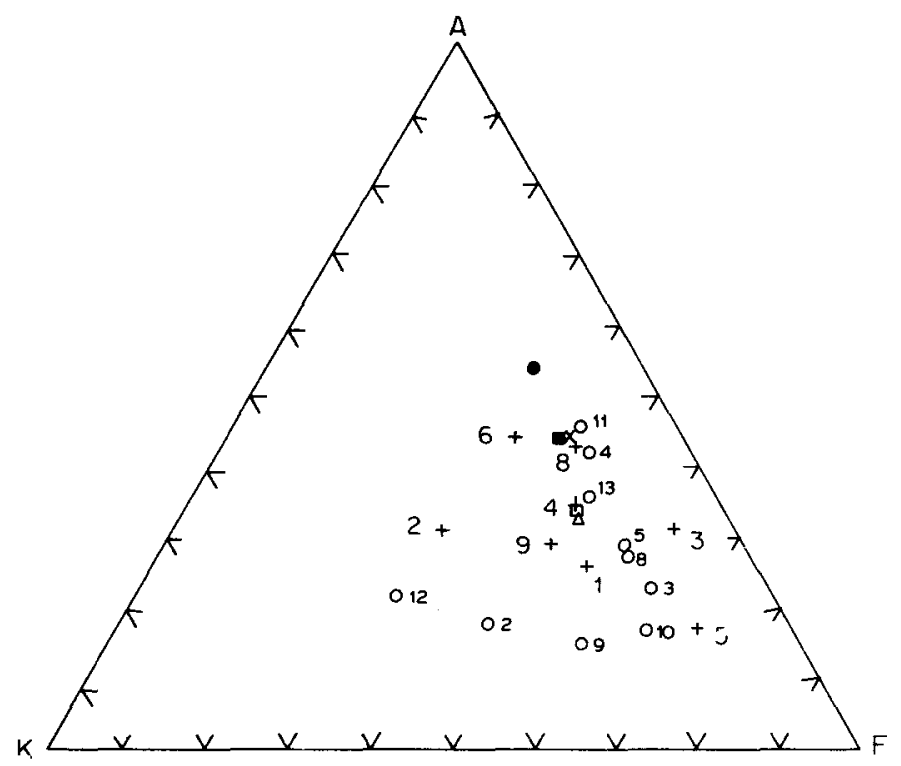

Figure 9. AKF diagram for the Vaikrita rocks and the Munsiari Fm., compared with average pelite, shales, Symbols same as in figure 8. $A=\left(\mathrm{Al}_{2} \mathrm{O}_{3}+\mathrm{Fe}_{2} \mathrm{O}_{3}\right)-\left(\mathrm{Na}_{2} \mathrm{O}+\mathrm{K}_{2} \mathrm{O}+\right.$ $\mathrm{CaO}), \mathrm{K}=\mathrm{K}_{2} \mathrm{O}$ and $\mathrm{F}=\mathrm{FeO}+\mathrm{MgO} . \mathrm{ACF}, \mathrm{A}=\left(\mathrm{Al}_{2} \mathrm{O}_{3}+\mathrm{Fe}_{2} \mathrm{O}_{3}\right)-\left(\mathrm{Na}_{2} \mathrm{O}+\mathrm{K}_{2} \mathrm{O}\right), \mathrm{C}=\mathrm{CaO}$, $\mathrm{F}=\mathrm{FeO}+\mathrm{MgO}$. 


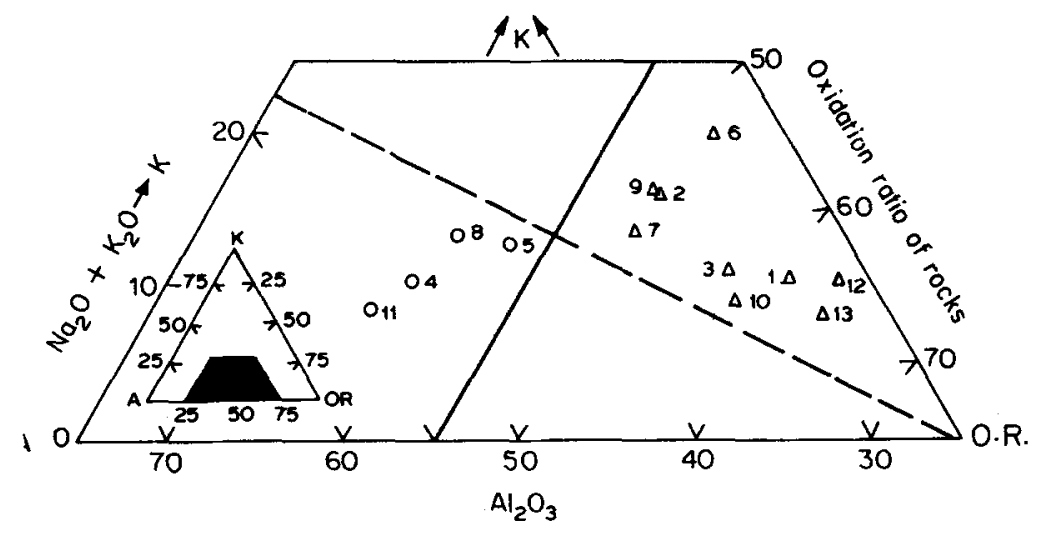

Figure 10. 'KA, OR Diagram' $\mathrm{K}=\left(\mathrm{K}_{2} \mathrm{O}+\mathrm{Na}_{2} \mathrm{O}\right), \mathrm{A}=\mathrm{Al}_{2} \mathrm{O}_{3}, \mathrm{O} . \mathrm{R}$. = Oxidation Ratio. For rocks of the Vaikrita Group showing their distribution in sillimanite-bearing $(\Theta)$ and sillimanite-free $(\Delta)$ fields, after Goel and Chaudhari (1979).

Table 3. Chemical analyses of the rocks of the Munsiari Formation.

\begin{tabular}{lrrrrrrrrrr}
\hline Oxide/samples & $\mathrm{D}-12$ & $\mathrm{KV}-12$ & $\mathrm{KV}-35$ & $\mathrm{~A}-63$ & $\mathrm{~A}-57$ & $\mathrm{~A}-31$ & $\mathrm{~A}-25$ & $\mathrm{KV}-228$ & $\mathrm{KV}-231$ \\
\hline $\mathrm{SiO}_{2}$ & 69.97 & 69.76 & 46.62 & 70.98 & 68.26 & 63.12 & 65.00 & 53.68 & 68.21 \\
$\mathrm{TiO}_{2}$ & 0.27 & 0.00 & 2.49 & 0.50 & 0.70 & 0.50 & 0.70 & 0.54 & 0.70 \\
$\mathrm{Al}_{2} \mathrm{O}_{3}$ & 14.54 & 16.44 & 22.42 & 14.80 & 15.54 & 20.37 & 15.44 & 24.25 & 16.04 \\
$\mathrm{Fe}_{2} \mathrm{O}_{3}+\mathrm{FeO}$ & 3.31 & 2.46 & 15.70 & 4.66 & 4.68 & 5.89 & 6.21 & 4.83 & 4.01 \\
$\mathrm{MgO}$ & 3.42 & 0.75 & 5.13 & 1.30 & 1.02 & 1.31 & 1.23 & 6.16 & 2.56 \\
$\mathrm{CaO}$ & 0.95 & 1.01 & 0.71 & 1.01 & 2.24 & 0.45 & 5.40 & 0.24 & 0.67 \\
$\mathrm{Na}$ & 2.02 & 2.80 & 0.61 & 2.00 & 5.00 & 2.80 & 4.40 & 0.43 & 1.50 \\
$\mathrm{~K}_{2} \mathrm{O}$ & 4.07 & 4.90 & 3.60 & 3.00 & 1.20 & 4.30 & 2.50 & 5.25 & 5.00 \\
$\mathrm{P}_{2} \mathrm{O}_{5}$ & 0.38 & 0.03 & 0.41 & 0.18 & 0.23 & 0.04 & 0.14 & 0.09 & 0.27 \\
$\mathrm{Total}$ & 98.93 & 98.15 & 97.69 & 98.43 & 98.87 & 98.78 & 99.02 & 95.47 & 98.96 \\
\hline
\end{tabular}

D-12 Mylonitized augen gneiss, Duk Gad, Chirkala, Eastern Dhauli valley.

KV-12 Mylonitized Granite, North of Gangoligaon. Eastern Dhauli valley.

KV-35 Garnetiferous-muscovite-chlorite gneiss. Munsiari, Gori valley.

A-63 Biotite schist. Jhuni. Saryu valley.

A-57 Mylonitized gneiss. Tarspil. Sundardhunga River. Pindar valley.

A-31 Garnetiferous mica schist, between Jaloli and Bhadang. Pindar valley.

A-25 Mylonitized augen gneiss, near Khati. Pindar valley.

KV-228 Chlorite-sericite schist, Tapovan, Western Dhauli valley.

KV-23I Sericite-chlorite schist. Shelang. Alaknanda valley.

The diagrams show that the majority of the rocks of the Vaikrita Group (circle with dot) lie in the field of pelites; one lies within the boundary of greywackes, while three are far removed. Two of these three samples (Nos. D-24, D-42) are rich in carbonates (and thus confined within the field of calca reous shales), and the third is granite-gneiss in composition and rich in tourmaline and biotite. These features represent compositional variations of the parental sediments. The lithological subdivision as given in table 1 is thus confirmed by the chemographic relation as well. 
The chemical analyses of metamorphics of the Munsiari Fm (+) also fall within the field of pelites and at the boundary of the greywacke field (figure 9). Thus the two groups of rocks are chemically not much different, although have entirely different mineral assemblages resulting from their contrasting grades of metamorphism, as revealed by their mineralogy (see earlier section).

\subsection{Bulk rock composition and formation of sillimanite and kyanite}

The analyses of rocks of the Vaikrita Group were plotted on KA-OR diagram (figure 10) following the method suggested by Goel and Chaudhari (1979). The rocks fall in two groups - one in the sillimanite-bearing field (SB) and the other in the sillimanite-free (SF). It is obvious that the bulk composition of the majority of rocks of the lower Vaikrita Group was not suitable for the formation of sillimanite, although they had attained the high grade of metamorphism up to upper amphibolite facies, as indicated by various mineral assemblages. It seems that higher oxidation of rocks and their higher alkali content favoured stabilization of muscovite and inhibiting the reaction muscovite + quartz $=$ sillimanite $+\mathrm{K}$-feldspar $+\mathrm{H}_{2} \mathrm{O}$, to take place on a wider zone.

$\mathrm{The} \mathrm{MgO} /(\mathrm{MgO}+\mathrm{FeO})$ mole ratio of the Vaikrita rocks shows that the $M /(M+F)$ values are more than $\mathbf{0 . 5 4}$ for the bulk of the kyanite-bearing rocks. These values are in conformity with the observation of Naggar and Atherton (1970) that kyanite in the medium-grade metapelites would not form if these values were lower than 0.54 . Later, Atherton and Brotherton (1972) suggested that kyanite can form even in rocks with lower $M /(M+F)$ values resulting from higher modal percentage of garnet and iron ores. Similar trend is discernible in the rocks of the Pandukeshwar Fm. (as noticed $1 \mathrm{~km}$ south of Urthing in the valley of East Dhauli) having $M /(M+F)$ values of 0.65 and 0.73 respectively, the former containing kyanite with garnet and the latter free of garnet. This clearly suggests the effect of bulk-rock chemistry on the development of kyanite and sillimanite in the rocks. It tulus appears that the rocks of the Vaikrita Group actually represent a medium to high grade of metamorphism and the absence of kyanite and/or sillimanite in a number of rocks may be attributed to their bulk-rock compositions.

\section{Acknowledgements}

The work described in this paper forms a part of KSV's project on the Great Himalaya, sponsored by the Department of Science and Technology, Government of India. The authors thank Dr B L Sharma, Geology Department, University of Rajasthan, Udaipur for facilities of chemical analysis and photomicrographs. They are very grateful to Dr R K Srivastava of Rajasthan University, Dr G C S Gaur of Wadia Institute of Himalayan Geology, Dehradun for helping in chemical analyses. Critical reviews on this manuscript by Dr R S Sharma, Banaras Hindu University, Varanasi, Dr A B Roy, Department of Geology, University of Rajasthan, Udaipur and Dr P K Bandopadhyay, Department of Geological Sciences, Jadavpur University, Calcutta are gratefully acknowledged.

\section{References}

Agrawal L: Pandey, Atma Ram and Powar K B $1972 \mathrm{Him}$. Geol. 2145

Althaus E, Karotke E, Nitsch K H and Winkler H G F 1970 Neues. J. B. Miner. Mh. 7325

Atherton M P and Brotherton M S 1972 Scotland J. Geol. 8203 
Auden J B 1937 Rec. Geol. Surv. India 71407

Berthelsen A 1951 Saer. Meddl. Dansk. Geol. Forening 12102

Bodenhausen J W A. De Booy T. Egler C G and Nitjhuis H J 1964 Report 22nd Int. Geol. Cong. Delhi, Sec. 11,101

Bordet P 1961 Centre Nat. Recher. Sci. Paris p. 275

Bordet P 1961 Recherches geologiques dans l'Himalaya du Nepal Region du Makalu, (Paris: CNRS), p. 275

Bordet P 1971 Recherches geologiques dans l'Himalaya du Nepal, region de la Thakkhola Chap. VII. I,

(Paris: CNRS), (eds) M Colchen, D Krummanecher. P Le Fort. R Mouterde and M Remy

Bordet P, Colchen M and Le Fort P 1972 Him. Geol. 2537

Cannon R T 1966 Am. Jour. Sci. 264 526-542

Chatterjee N D and Johannes W 1974 Contrib. Miner. Petrology 4889

Das A K. Bakliwal P C and Dhoundiyal D P 1975 Geol. Surv. India Musc. Pub. Calcutta 24115

Dave V K S and Rawat B S 1968 Res. J. Roorkee Univ. 1097

Evans B W 1965 Am. J. Sci. 263647

Fuchs G R and Frank W 1970 Jahrb. Geol. Bundes 181

Gansser A 1964 Geology of the Himalavas (New York: Interscience) p. 289

Goel O P and Chaudhari M W 1979 Lithos, 12153

Goldsmith J R and Newton R C 1977 Am. Miner. 621063

Greisbach C L $1891 \mathrm{Mem}$. Geol. Surv. India 231

Greisbach C L 1893 Rec. Geol. Surv. India 2619

Guidotti C V 1970 J. Petrol. 11277

Gupta L N 1978 Bull. India Geol. Assoc. 1163

Hagen T 1958 Jarbh. St. Gallischen Naturf. Gessel 763

Hashimoto H. Ohta Y and Akiba G 1973 Geology of the Nepal Himalalas (Japan: Himalayan Committees of Hakkaido Univ. Sapporo)

Heim A and Gansser A 1939 Denkschr. Schn'eiz Naturf. Gessel 731

Hirschberg A and Winkler H G F 1968 Contrib. Miner. Petrol. 1817

Holdaway M J 1971 Am. J. Sci. 27197

Hoschek G 1969 Contrib. Miner. Petrol. 22208

Jangpangi B S, Dhoundiyal D P. Kumar G and Dhaundiyal J N 1978 Him. Geol. 8(II) 837

Jaros J and Kalvoda J $1976 \mathrm{Him}$. Geol. 6176

Kretz R 1966 J. Petrol. 768

Kumar G, Mehdi S H and Prakash G $1970 \mathrm{~J}$. Palaeontol. Soc. India 1586

Lombard A 1958 Denkschr. Schwaiz. Naturf. Gassel 821

Le Fort P 1971 Recherches geologiques dans I'Himalaya du Nepal region de la Thakkhola. Chap. III (ed) (Paris: CNRS)

Liou J G $1973 \mathrm{~J}$. Petrol. 14381

Mackenzie W S 1954 Miner. Mag. 30354

Mehdi S H, Kumar G and Prakash 1972 Him. Geol. 2481

Misra R C and Bhattacharya A R $1977 \mathrm{Him}$. Geol. 7133

Miyashiro A 1973 Metamorphism and Metamorphic Belts, (London: George Allen), p. 492

Naggar M H and Atherton M P 1970 J. Petrol. 11549

Nautiyal S P, Jangpangi B S, Singh P. Guhasarkar T K, Bhate V D. Raghavan M R and Sahai T N 1964 Report 22nd Int. Geol. Congr. 11 I

Orville P M 1969 Am. J. Sci. 26764

Pande I C and Saxena M N 1968 Pub. Centre Adv. Stud. Geol. Punjab Univ. Chandigarh 41

Pecher A 1977 in Himalaya, Sciences de la Terre (Pub. No. 268). (Paris: CNRS), p. 301

Pettijohn F J 1963 Data of Geochemistry, 6th ed., US Geol. Surv. Prof. Paper 440-S, Si-S21

Pettijohn F J 1969 Sedimentary Rocks, 2nd Indian reprint (Calcutta. New Delhi, Bombay: IBH Pub. Co.) p. 718

Powar K B 1972 Him. Geol. 234

Powell C M A and Conaghan P J 1973 Earth Planet. Sci. Lett. 201

Richardson S W, Gilbert M C and Bell P M 1969 Am. J. Sci. 267259

Saxena M N 1971 Tectonophysics 12433

Shapiro L and Brannock W W 1972 US Geol. Surv. Prof. Paper. 1144-A. p. 56

Sharma R S and Narayan V 1975 Neues. Jb. Miner. Abh. 124190

Shaw D M 1956 Bull. Geol. Soc. Am. 69919 
Srikantia S V and Bhargava ON 1978 in Tectonic Geologl of Himalava(ed) P S Saklani (New Delhi: Today \& Tomorrow's)

Thakur V C 1977 in Himalaya. Sciences de la Terre (Pub. No. 268). (Paris: CNRS). p. 433

Thompson A B 1976 Am. J. Sci. 276401

Tuttle O F and Bowen N L $1958 \mathrm{Mem}$. Geol. Soc. Am. p. 74

Valdiya K S $1962 \mathrm{~J}$. Geol. Soc. India 27

Valdiya K S 1973 Proc. Sem. Geodynamics of Himalayan Region. NGRI. Hyderabad. pp. 204-205 (Abstract)

Valdiya K S 1977 in Himalaya, Sciences de la Terre (Pub., No. 268), (Paris: CNRS), p. 449

Valdiya K S 1979 J. Geol. Soc. India 20145

Valdiya K S 1980 Tectonophy'sics 66323

Valdiya K S 1981 Zagros-Hindukush, Himalaya Geodynamic Evolution (eds) H K Gupta and F M Delany (Washington: Am. Geophysical Union), Vol. 3, p. 87

Vernon R H 1968 Aust. J. Petrol. 9 I

Winkler H G F 1967 Petrogenesis of Metamorphic Rocks. 2nd ed. (New York: Springer-Verlag)

Winkler H G F 1974 Petrogenesis of Metamorphic Rocks, 4th ed. (New Delhi: Springer Int. Student Ed.) p. 334

Winkler H G F 1976 Petrogenesis of Metamorphic Rocks, 5th ed. (Berlin: Springer-Verlag) 